\title{
Full Receptor Agonist
}

National Cancer Institute

\section{Source}

National Cancer Institute. Full Receptor Agonist. NCI Thesaurus. Code C154899.

A class of substances that binds to and activates a receptor and induces the maximal biological response. 